\title{
The Effect of Corporate Social Responsibility on Brand Building
}

\author{
Ayogyam Alexander ${ }^{1,2}$, Amo Francis ${ }^{3}$, Lydia Asare Kyire ${ }^{2} \&$ Hudu Mohammed ${ }^{4}$ \\ ${ }^{1}$ School of Graduate Studies Research and Innovation, Kumasi Polytechnic, Ghana \\ ${ }^{2}$ Department of Entrepreneurship and Finance, Kumasi Polytechnic, Ghana \\ ${ }^{3}$ Department of Marketing, Kumasi Polytechnic, Ghana \\ ${ }^{4}$ Department of Mathematics and Sciences, Kumasi Polytechnic, Ghana
}

Correspondence: Ayogyam Alexander, P. O. Box GC 37 Anloga, Kumasi, Ghana. E-mail: kingmulleraa@yahoo.com

Received: February 24, 2014

Accepted: March 25, 2014 Online Published: May 21, 2014

doi:10.5539/ijms.v6n3p126

URL: http://dx.doi.org/10.5539/ijms.v6n3p126

\begin{abstract}
The objective of this research has been to find out the effect Corporate Social Responsibility (CSR) would have on the building of future brands in an organisation. Some beneficiary communities were segmented into focus groups for discussions on the ramifications of CSR. The discussions brought forth three main ramifications (namely; stakeholder expectations, collaborations and research \& Development) which eventually led to the discovery of fifteen variables. A questionnaire was then prepared with these variables in mind. A sample of 200 employees from ten organizations was selected as respondents before these questionnaires were administered. The data collected on these variables were then analysed using factor analysis. The analysis revealed that, there exist strong correlations between some of the variables such as OLBS and PIC; CTP and PIC; COO and RCL and others as shown in the correlation matrix table. The analysis further indicated that the variables PIC, RCL, PSE, DVD, TT and OCD with Eigen values greater than 1 reflects a decreasing strength towards brand building as shown in the total variance table. Out of the 15 variables, component 1 with a loading of 10.840 best affects brand building instead of component 2 .
\end{abstract}

Keywords: corporate social responsibility, effect on brand building, beneficiary communities and ramifications

\section{Introduction}

\subsection{The Research Motive and the Role of CSR}

The study seeks to probe deeper understanding of factors which influences brand building. The main motive of this study is to provide unique insights to inspire and guide the development of varying skills in product design.

Companies that authentically and deeply tie their social causes to the essence of their brand will be winners at all times. The problem most organisations have is to be able to build products that would be well accepted in the market. Different organisations adopt diverse strategies to curb the situation. This research seeks to find out how innovative the organisation could be through the use of Corporate Social Responsibility (CSR). CSR is the act of showing to the community how caring they are by undertaking social programmes that are dear to the heart of the dwellers. It is a practice that can be described as a fad even though many organisations have integrated it into their management process (Guthey, Langer, \& Morsing, 2006). The priority given to CSR by organisations have been uneven since some of them perceive CSR as a risk reducing tool whiles others use it as a vehicle to drive innovations. This study sought to acknowledge the effects CSR has on the innovation driven machinery of some organisations in Ghana. The kinds of brands built by organisations are usually anchored to the ramifications of Corporate Social Responsibility (CSR). The consequences of globalisation has forced firms to be socially responsible through their innovative skills by building brands that could help in reducing the unnecessary imbalances built by global effects. The study therefore wishes to discover how a socially responsible organisation could positively aid brand building. It has been proven by literature that branding has the ability to convert undifferentiated or convenience goods into shopping or speciality goods. Due to that, it is worth inquiring if CSR could contribute to brand quality and first mover advantage upon introduction. Since innovativeness is a 'cost add-on', organisations are to ensure that the brand they build would reflect the values of the entire society so that customers would espouse the emerging brand. It is the responsibility of firms to ensure 
that whatever cost they incur is metamorphosed into beams of benefits. Since CSR has always been a cost related activity, organisations must endeavour to derive some benefits from it to lessen the risk factor as proposed by (Hockerts, 2008). The CSR per say may not necessary be a holistic engine to drive customer desire hence the relevance of this study is to research into areas where CSR may help whip up the purchasing power of these customers. This herculean task has been embarked upon to find out how CSR can support the research conducted by Davis (2002) which claimed that; $72 \%$ of customers will pay a $20 \%$ premium for their preferred brand; $50 \%$ will pay $25 \%$ more; $40 \%$ will pay $30 \%$ more; $25 \%$ say the price does not matter; more than $70 \%$ use brands to guide buying decisions and $50 \%$ are brand driven.

\subsection{Relating to the Society through CSR}

The organisation has been entrusted some degree of power and autonomy to operate of which they stand accountable to the society. This was described as the iron law of responsibility. Since firms need to maintain and sustain their composure, they must not abuse the power as they are bound to relate back to the society through CSR (Post, Preston, \& Sachs, 2002). The society as a stakeholder in business entities must be managed strategically to unearth the myriad of factors which are likely to influence directly or indirectly the ability of the firm to achieve success (Freeman \& Velamuri, 2006). According to Mitchell, Agle and Wood (1997); Morsing and Beckmann (2006); CSR has become a source for stakeholder identification, involvement and communication in the event that the stakeholder must be managed as posited by Freeman and Velamuri above. The aim of stakeholder management is thus to analyse how a company can serve its customers and be lucrative.

Tushman \& Anderson (1986) and Lazonick (2001) differentiated innovating enterprise from merely optimizing enterprise by characterising innovative companies as transforming technological and/or market conditions so as to differentiate themselves from other firms in an industry to gain sustained advantage. This indicates that innovative firms must be 'brand building lovers'. The brand builders are selective in their innovations and in their bid to implementing research findings (Servatius, 1994; Venkataraman, 1999). The fact is that creativity is enhanced by people collaborating across different disciplines, product groups and industries which help to improve the way business is done by every employee at every level and every function within the organisation.

\subsection{User Community Influence on Brand Building}

The user-driven innovation described by Eric Von Hoppel $(1979,1986,2001)$ indicates that user communities have the ability to initiate and develop exceedingly complex products sometimes even without any specific manufacturer involvement. In view of this model, CSR is expected play a significant role in the perception of the communities as they embark on initiation and development as indicated by Eric Von Hippel above. The fact that, unmet needs of customers require solutions, it is just proper to hold on to the argument put up by Kanter Rosabeth Moss (1999) that firms should resort to the use of social issues as learning laboratory for identifying the needs and also for developing solutions that create new markets. Stakeholder expectation is a variable linked to CSR and corporate marketing concepts. In the last decade, issues linked to CSR have been described as drivers of public opinion (Dawkins \& Lewis, 2003) and corporate reputation (Frombrun et al., 2000). Researchers have also shown that antecedents of stakeholder responses to corporate behaviours were their beliefs and expectations of corporate social responsibility (Sen \& Bhattacharya, 2001). This presupposes that consumers form expectations about the ethicality of corporate behaviour and again the extent to which consumers will reward or punish company's behaviour is a function of expectation of CSR (Creyer \& Ross, 1997). It is also reiterated by Hallahan (2001) that the responsiveness of individuals depends on the congruence between expectations and companies actions.

Various literatures have indicated links and impacts of CSR on brand evaluation, brand choice and brand recommendation (Klein \& Dawar, 2004). Gardberg and Fombrun (2006) also stated that investments in research and development and advertising can contribute to a differentiation strategy by helping companies to build brand equity. Furthermore, it has been argued that firms that are able to behave in a responsible way with secondary stakeholders such as the community gain a reputation of trustworthy among customers, suppliers and employees by addressing short and long term effects on brands (Dekimpe \& Hanssens, 1999; Dekimpe, Hanssens, Nijs, \& Steenkamp, 2005).

Firms can no longer present any ordinary product to the market but rather, they must deliver consistent brand promise to each share holder. In view of this, top management must superintend over a strong strategic corporate perspective (Hatch \& Schultz, 2003). It has become acceptable that consumers show positive changes in their purchasing towards businesses that are demonstrating environmental responsibility (Menon \& Menon, 1997). Corporations have no option than to employ proactive strategies to take advantage of this issue (Zeithml \& 
Zeithml, 1984). This view was supported by Brady (2003) that corporate brands attract increasing attention and so there is a pressing need for those firms to espouse and implement responsible practices.

\subsection{Benefits of CSR}

Some benefits were identified as a result of CSR implementation. Luo and Bhattacharya (2006) were noted to have indicated that CSR can secure competitive advantage and financial returns to the firm whiles Hoeffler and Keller (2002) claims CSR builds brand awareness. Other researchers, including Luo and Bhattachary (2006); Uggla (2006); Vaaland et al. (2008); Werther Jnr and Chandler (2005) also found that CSR is capable of creating brand legitimacy. It is however well noted that, despite these plethora of benefits, only a few corporations have fully leveraged the brand building opportunities that CSR offer (Blumenthal \& Bergstorm, 2003). Hoeffler and Keller (2002) in view of this revelation under scored the point that, when firms get involved in strategic CSR, they would be able to create fresh brand meaning and also push up the existing stakeholder association more notches higher. It has also been found that any brand that has its basis anchored to a CSR program empowers firms to fulfil the brands promise and cultivating trust based relationship (Kitchin, 2003). To this effect, firms wishing to attract potential stakeholders must showcase actions that seek to promote a particular social good (Castaldo et al., 2009). This gives an indication that CSR has a role to play when it comes building brands.

\subsection{The Research Model and Research Questions}

Based on the literature above, it can be deduced that CSR having been done properly can give way to effects such as; Research and Development, Collaboration, Stakeholder expectations as shown in the figure below. Each of these has a greater impact on idea creation and innovation which can eventually lead to the building of appropriate brands.

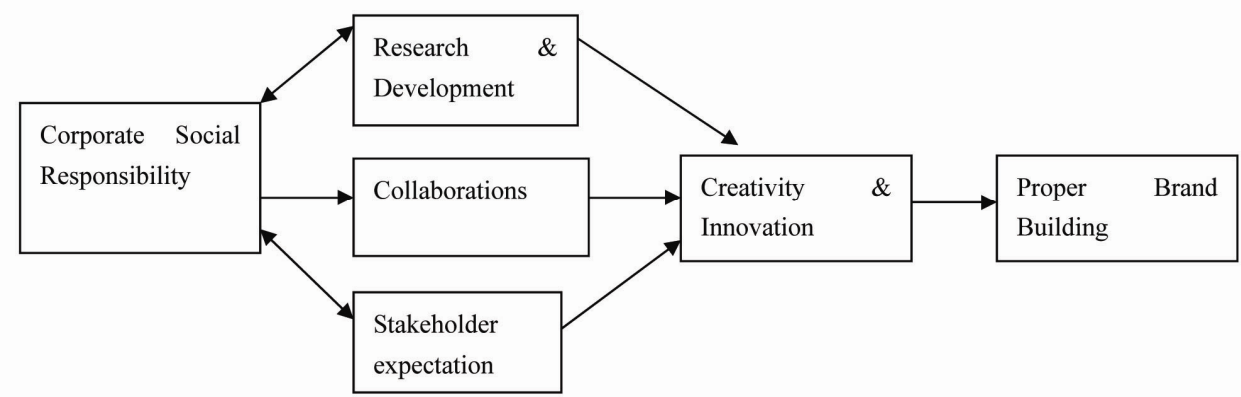

Figure 1. A model developed for enhancing brand building through CSR

From the figure, the double edged arrow connecting Research and Development and CSR indicates that each one of them can lead to the other. The same relationship exists between stakeholder expectation and CSR. This study is concentrating on the ramifications of CSR, hence the focus is on movement of arrows from the left to the right in the figure. If a company is socially responsible, it may have the opportunity to co-opt members of the society who can be useful partners in creativity and innovation. The company would then collaborate with its suppliers, beneficiaries of the CSR program and others since a platform has been created to solicit ideas for innovation. Secondly, the CSR platform created may avail the need for some research that would lead to creativity and innovation. Thirdly, the attitude of stakeholders towards the CSR program may show clearly the acceptance of the people and their future expectations. Based on these expectations, some relevant ideas would be conceived leading to innovativeness. When the firm has become astute in innovation, it is then likely to build brands that are likely to ignite the interest of the public. These developments have necessitated the need to find answers to the following questions;

- How will the firm identify research areas after indulging in CSR and how do those areas affect brand building?

- What will bring about company-society collaboration and would that affect brand building?

- What causes stakeholders expectations after a CSR program and how will those causes affect brand building? 


\section{Method}

\subsection{Selection of the Units}

The units for the study were drawn from societies where a CSR program has once taken place and the firm that initiated and implemented the program. The units from a society were chosen at random but the units from the designated companies were selected using the purposive sampling procedure because not all units were crucial to the success of this study. The beneficiary communities were selected based on the number of CSR programs they have benefited in the past and the population of the community. A total of five communities were selected based on the criteria stated above and the respondents were randomly selected to form focus groups. These respondents from the communities assisted in gathering the possible ramifications as indicated in table 1 below. Some employees from the CSR implementing organizations were purposively selected because not all units were considered appropriate based on the framework of the study. These respondents basically responded to the impact of some independent variables on the firm's ability to build a strong brand.

\subsection{Gathering Variables through Focus Groups, Sample Size and Data Collection Instrument}

Focus group discussions were then organised in each community in smaller groups of 10 persons. At each group discussion (20 groups), views were solicited based on the consequence of a CSR programme. The units of the groups were engaged in fruitful discussions to find how the aftermath of CSR could facilitate brand building. The variables for the study were derived from the views expressed at the group discussions. After the preliminary exercise, variables which were gathered from the field became very important inputs for the questionnaire which was specially designed for 200 employees (being the sample size for the research $\mathrm{n}=200$ ) who were basically selected using purposive sampling.

The data collection was made possible through the use of a self administered questionnaire as a follow up to the group discussion. In analysing the data, factor analysis was adopted to rank the variables in the order of their contribution towards brand building exercises. Again some combinations of the variables were put together to analyse their collective effect on brand building. Table 1 below showcases the ramifications of CSR and the variables deduced from the responses received from the group discussions.

Table 1. Variables derived after the introduction of CSR

\begin{tabular}{|c|c|}
\hline Ramifications of CSR & Variables Arising out of Ramification \\
\hline \multirow[t]{5}{*}{ Collaborations between parties could bring about ideas } & 1. Pulling together of intellectual capacity or expertise(PIC) \\
\hline & Rising of commitment level of partners(RCL) \\
\hline & Presence of synergetic effects(PSE) \\
\hline & Demand for variety of deliverables(DVD) \\
\hline & Transfer of technology(TT) \\
\hline \multirow[t]{5}{*}{ Research and Development could bring about ideas } & Opportunity to correct defects on existing products(OCD) \\
\hline & Opportunity to find new uses for existing products(ONU) \\
\hline & Opportunity to find new users for existing products(ONUS) \\
\hline & Opportunity to follow fashion by improving products(OFF) \\
\hline & Opportunity to learn better standards(OLBS) \\
\hline \multirow[t]{5}{*}{ Stakeholder expectations could bring about ideas } & Change of focus of the firm's production line(CFF) \\
\hline & Change in policy making strategies by the firm(CPM) \\
\hline & Change in organizational objectives $(\mathrm{COO})$ \\
\hline & Change in technology application during production(CTP) \\
\hline & Change in the cost of production(CTA) \\
\hline
\end{tabular}

Source: from the field work and contributions from literature.

\section{Results and Discussions}

\subsection{Factor Analysis}

Table 2. KMO and Bartlett's test

\begin{tabular}{lll}
\hline Kaiser-Meyer-Olkin Measure of Sampling Adequacy. & .600 \\
\hline Bartlett's Test of Sphericity & Approx. Chi-Square & 141.727 \\
& df & 105 \\
& Sig. & .010 \\
\hline
\end{tabular}


Table 3. Correlation matrix ${ }^{\mathrm{a}}$

\begin{tabular}{|c|c|c|c|c|c|c|c|c|c|c|c|c|c|c|c|c|}
\hline & & PIC & RCL & PSE & DVD & $\mathrm{TT}$ & OCD & ONU & ONUS & OFF & OLBS & $\mathrm{CFF}$ & CPM & $\mathrm{COO}$ & CTP & CTA \\
\hline \multirow[t]{15}{*}{ Correlation } & PIC & 1.000 & & & & & & & & & & & & & & \\
\hline & $\mathrm{RCL}$ & -.119 & 1.000 & & & & & & & & & & & & & \\
\hline & PSE & -.080 & -.032 & 1.000 & & & & & & & & & & & & \\
\hline & DVD & -.045 & -.012 & .069 & 1.000 & & & & & & & & & & & \\
\hline & $\mathrm{TT}$ & -.137 & .028 & -.020 & -.099 & 1.000 & & & & & & & & & & \\
\hline & OCD & .132 & .019 & -.133 & -.708 & -.153 & 1.000 & & & & & & & & & \\
\hline & ONU & -.056 & -.008 & .145 & .019 & -.109 & -.020 & 1.000 & & & & & & & & \\
\hline & ONUS & -.026 & .133 & -.691 & .063 & -.044 & .028 & -.117 & 1.000 & & & & & & & \\
\hline & OFF & .088 & .100 & .590 & .019 & -.009 & .081 & -.009 & -.093 & 1.000 & & & & & & \\
\hline & OLBS & .703 & .026 & -.138 & -.073 & .002 & .066 & -.048 & -.096 & -.024 & 1.000 & & & & & \\
\hline & $\mathrm{CFF}$ & .034 & .862 & -.036 & .128 & -.016 & .853 & .041 & .168 & -.058 & -.048 & 1.000 & & & & \\
\hline & CPM & -.110 & -.037 & .168 & .069 & .047 & .005 & -.050 & -.026 & .146 & .012 & .041 & 1.000 & & & \\
\hline & $\mathrm{COO}$ & -.105 & -.748 & .022 & -.020 & -.038 & .042 & .016 & -.116 & .048 & .106 & .043 & .129 & 1.000 & & \\
\hline & CTP & .871 & -.078 & -.165 & -.029 & .026 & .719 & -.025 & -.029 & -.159 & .075 & -.053 & -.045 & .066 & 1.000 & \\
\hline & CTA & .000 & .056 & .046 & -.050 & .083 & -.173 & .027 & -.012 & .091 & -.773 & .038 & -.012 & -.087 & -.064 & 1.000 \\
\hline
\end{tabular}

Note. ${ }^{\text {a. }}$ Determinant $=.480$

Table 4. Total variance explained

\begin{tabular}{|c|c|c|c|c|c|c|c|c|c|}
\hline \multirow[b]{2}{*}{ Component } & \multicolumn{3}{|c|}{ Initial Eigenvalues } & \multicolumn{3}{|c|}{ Extraction Sums of Squared Loadings } & \multicolumn{3}{|c|}{ Rotation Sums of Squared Loadings } \\
\hline & Total & $\%$ of Variance & Cumulative \% & Total & $\%$ of Variance & Cumulative \% & Total & $\%$ of Variance & Cumulative $\%$ \\
\hline 1 & 1.659 & 11.058 & 11.058 & 1.659 & 11.058 & 11.058 & 1.626 & 10.840 & 10.840 \\
\hline 2 & 1.414 & 9.429 & 20.486 & 1.414 & 9.429 & 20.486 & 1.447 & 9.646 & 20.486 \\
\hline 3 & 1.380 & 9.200 & 29.687 & & & & & & \\
\hline 4 & 1.234 & 8.229 & 37.916 & & & & & & \\
\hline 5 & 1.202 & 8.014 & 45.930 & & & & & & \\
\hline 6 & 1.064 & 7.091 & 53.021 & & & & & & \\
\hline 7 & .996 & 6.643 & 59.664 & & & & & & \\
\hline 8 & .952 & 6.346 & 66.010 & & & & & & \\
\hline 9 & .883 & 5.884 & 71.894 & & & & & & \\
\hline 10 & .832 & 5.548 & 77.442 & & & & & & \\
\hline 11 & .810 & 5.402 & 82.844 & & & & & & \\
\hline 12 & .722 & 4.816 & 87.660 & & & & & & \\
\hline 13 & .680 & 4.531 & 92.191 & & & & & & \\
\hline 14 & .649 & 4.327 & 96.517 & & & & & & \\
\hline 15 & .522 & 3.483 & 100.000 & & & & & & \\
\hline
\end{tabular}

Note. Extraction Method: Principal Component Analysis. 
Table 5. Rotated component matrix ${ }^{\mathrm{a}}$

\begin{tabular}{lll}
\hline & Component & \\
\hline & 1 & \\
CTP & -.581 & \\
OCD & -.534 & .427 \\
PSE & .489 & \\
OLBS & -.432 & \\
PIC & -.391 & \\
CTA & .372 & \\
TT & & \\
DVD & & -.672 \\
ONUS & & .438 \\
COO & & -.386 \\
CFF & & .379 \\
CPM & .212 & .358 \\
OFF & .239 & -.307 \\
RCL & & .206 \\
ONU
\end{tabular}

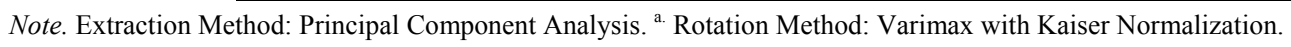

\subsection{Analysis of the Results}

The factor analysis used generated four tables as shown in the results presentation above. The four tables include correlation matrix table, the Kaiser-Meyer-OIkin and Bartlett's test table, the total variance explained table and the rotated component matrix table. The results display the effect of the independent variables (as in table one) on the brand building capabilities of the firm.

From table 2, the Kaiser-Meyer-OIkin (KMO) measure of 0.600 is an indication that enough data per each variable was collected for the factor analysis. This shows that the data satisfies the adequacy test according to (KMO). The control spherical Bartlett's $\mathrm{p}=0.010$ shows that principal component analysis is meaningful. In this analysis, data was grouped according to their correlation with the aim to capture those factors that describe best the building of new brands.

The correlation matrix table (table 3 ) displays how each of the fifteen independent variables associates with the other fourteen variables. Also the determinant value under table 3 is 0.480 which is greater than the threshold value of 0.00001 . This therefore means that the factor analysis solution can be found. From the table, most of the associations have high correlation values (closer to 1). This means that the pairs are likely to have a collaborative effect on brand building and so they can be grouped together. The table shows clearly that PIC correlates strongly with OLBS and CTP, RCL correlates strongly with COO and CFF, PSE correlates strongly with ONUS, OFF and OCD, OCD also correlates strongly with CFF and CTP, OLBS correlates strongly with CTA. It is also clear from the table that PIC and CTA shows a correlation of 0.000 signifying no correlation. Each correlation figure that appears negative on table 3 indicates an inverse correlation between the variables concerned.

Based on the results on table 4 (the total variance explained) the variance is divided among 15 possible factors. Six factors namely PIC, RCL, PSE, DVD, TT, and OCD have Eigen values greater than 1 indicating their usefulness towards the building of new brands. The other nine factors display less information of usefulness towards the building of new brand in a descending order.

From the rotated factor matrix table (table 5), the 15 factors have been sorted into two overlapping groups of items known as components with a loading of 0.2 (absolute) or better. Hence any factor within the components whose loading is less than an absolute value of 0.2 do not have meaningful effect on the building of new brands. In the case of component 1, CTP, OCD, PSE, OLBS, PIC CTA OFF and RCL serve as a best combination of factors whose loadings are $-0.581,-0.534,-0.489,-0.432,-0.391$ and 0.372 respectively. Component 2 has a combination of factors consisting of PSE, ONU, RCL, OFF, CPM, CFF, COO, and ONUS. Each of the factors 
has loading which is greater than 0.2 (absolute) and can possibly affect the brand building of the firm. Table 5again indicates that the rotation sum of square loading for components 1 is 10.840 which is higher than component 2 with 9.646. This means that the combination in the component 1 best affects the building of the brand better than the combination in component 2 .

\section{Conclusion and Recommendation}

\subsection{Conclusions of the Study}

The study concludes that any company that undertakes Corporate Social Responsibility in Ghana is likely to initiate strong collaboration between the company and the other numerous stakeholders in the environment such as government agencies, individuals and business organisations. Stakeholders who enjoy the benevolence of the company's CSR become so committed to it, in terms of vision and mission. These stakeholders through their commitment status would lend their support in the form of ideas and initiatives. The company can take advantage of the stakeholder's commitment and support to develop new brands for the market. It is discovered that, the demand for variety of brands exist because of the goodwill accorded the company. Furthermore, it is realised that the combined effort of the company and that of the stakeholders in the community towards brand building surpasses what would have been the contribution of a single entity. The collaboration brings all parties together and that is likely to ignite transfer of technology. It has also been discovered that, rolling out CSR programs brings the companies closer to the community hence creating accessibility towards the conduct of research which impacts heavily on brand building. The company gets the opportunity to institute corrective measures in the procedural outlay so as to produce the desired brand. Finally, it has been discovered that the fifteen factors adopted for this study do not holistically give sufficient information for effective brand building but rather when they are put in their appropriate groups. Though it has been proven by the analysis that DVD and TT have individual differential effect on brand building, there is also a clear manifestation that these factors do not give any effect when combined with other factors.

\subsection{Recommendation to Future Researchers}

In light of these conclusions, the study recommends that future researchers could delve into the impact of CSR on the marketing of the new brand produced. The factors which would pave way for successful promotions, advertisement and sales must be identified and ranked.

\section{References}

Blumenthal, D., \& Bergstrom, A. J. (2003). Brand councils that care: Towards the convergence of branding and corporate social responsibility. Journal of Brand Management, 10(4/5), 327-341. http://dx.doi.org/10.1057/palgrave.bm.2540128

Brady, A. K. O. (2003). How to generate sustainable brand value from responsibility. Journal of Brand Management, 10(4/5), 279-289. http://dx.doi.org/10.1057/palgrave.bm.2540124

Castaldo, S., Perrini, F., Misani, N., \& Tencati, A. (2009). The missing link between corporate social responsibility and consumer trust: The case of fair trade products. Journal of Business Ethics, 84(1), 1-15. http://dx.doi.org/10.1007/s10551-008-9669-4

Creyer, E. H., \& Ross, W. T. (1997). The influence of firm behaviour on purchase intention: Do consumers really care about business ethics? Journal of Consumer Marketing, 14(6), 421-432. http://dx.doi.org/10.1108/07363769710185999

Davis, S. M. (2002). Brand Asset Management: Driving Profitable Growth through Your Brands. San Francisco: Josey Bass.

Dawkins, D., \& Lewis, S. (2003). CSR in stakeholder expectations: and their implication for company strategy. $J$. Bus. Ethics, 44(2/3), 185-193. http://dx.doi.org/10.1023/A:1023399732720

Dekimpe, M. G., \& Hanssens, D. M. (1999). Sustained spending and persistent response: A new look at long-term marketing profitability. Journal of Marketing Research. http://dx.doi.org/10.2307/3151996

Dekimpe, M. G., \& Steenkamp, E. M. (2005). Competitive reactions to advertising and promotional attacks. Marketing Science, 35-39.

Fomburn, C. J., Gardberg, N. A., \& Sever, J. M. (2000). The reputation Quotient:A multi stakeholder measure of corporate reputation. Journal of Brand Management, 7(4), 241-255. http://dx.doi.org/10.1057/bm.2000.10 
Freeman, R., \& Velamuri, S. (2006). A New Approach to CSR: Company Stakeholder Responsibility. In A. Kakabdse \& M. Morsing (Eds.), Corporate Social Responsibility (CSR): Reconciling aspiration with application. Palgrave Macmillan.

Gardberg, N. A., \& Fomburn, C. J. (2006). Corporate citizenship: Creating intangible assets across institutional environment. Academy of Management Review, 329-346. http://dx.doi.org/10.5465/AMR.2006.20208684

Guthey, E., Langer, R., \& Morsing, M. (2006). Corporate social responsibility is a management fashion. So what? In M. Morsing \& S. Beckmann (Eds.), Strategic CSR Communications (pp. 39-60). Copenhagen: DJOF Publishing.

Hallahan, K. (2001). The dynamics of issues activation and response: an issues processes model. Journal of Public Relations Research, 13(1), 27-59. http://dx.doi.org/10.1207/S1532754XJPRR1301_3

Hatch, M. J., \& Schultz, M. (2003). Bringing the corporation into corporate branding. European Journal of Marketing, 37(7/8), 1041-1065. http://dx.doi.org/10.1108/03090560310477654

Hockerts, K. (2008). Managerial Perceptions of the Business Case for Corporate Social Responsibility. CBSCSR Working Paper Series. Copenhagen Business School.

Hoeffler, S., \& Keller, K. L. (2002). Building brand equity through corporate societal marketing. Journal of Public Policy \& Marketing, 21(1), 78-89. http://dx.doi.org/10.1509/jppm.21.1.78.17600

Kanter, R. M. (1999). From Spare Change to Real Change: The Social Sector as a Beta Site for Business Innovation. Harvard Business Review, 77, 123-132.

Kitchin, T. (2003). Corporate social responsibility: A brand explanation. Journal of Brand Management, 10(4/5), 312-326. http://dx.doi.org/10.1057/palgrave.bm.2540127

Klein, J., \& Dawar, N. (2004). Corporate social responsibility and consumers' attributions and brand evaluations in a product-harm crisis. International Journal of Research in Marketing, 21, 203-217. http://dx.doi.org/10.1016/j.jiresmar.2003.12.003

Lazonick, W. (2001). Social Conditions of Innovative Enterprise: Economic Theory and Historical Transformation. Paper presented at the Penrosian Legacy Conference, 11-12 May 2001, Fontainebleau.

Luo, X., \& Bhattacharya, C. B. (2006). Corporate social responsibility, customer satisfaction, and market value. Journal of Marketing, 70(4), 1-18. http://dx.doi.org/10.1509/jmkg.70.4.1

Menon, A., \& Menon, A. (1997). Enviropreneurial marketing strategy: The emergence of corporate environmentalism as market strategy. Journal of Marketing, 61(1), 51-67. http://dx.doi.org/10.2307/1252189

Mitchell, R., Agle, B., \& Wood, D. (1997). Toward a Theory of Stakeholder Identification and Salience: Defining the Principle of and What Really Counts. The Academy of Management Review, 22, 853-886.

Morsing, M., \& Beckmann, S. (2006). Strategic CSR communication-an emerging field. København: DJØF Forlagene.

Post, J. E., Preston, L. E., \& Sachs, S. (2002). Redefining the Corporation: Stakeholder Management and Organizational Wealth. Stanford Business Books.

Sen, S., \& Bhattacharya, C. B. (2004). Doing better at doing good: When, why and how consumers respond to corporate social initiatives. California Management Review, 47, 9-25. http://dx.doi.org/10.2307/41166284

Servatius, H. G. (1994). Implementation eines Venture Managements. In H. C. Riekhof (Ed.), Praxis der Strategieentwicklung. Konzepte, Erfahrungen, Fallstudien. Stuttgart: Schäffer-Poeschel.

Tushman, M. L., \& Anderson, P. (1986). Technological Discontinuities and Organizational Environments. Administrative Science Quarterly, 31, 439-465. http://dx.doi.org/10.2307/2392832

Uggla, H. (2006). The corporate brand association base. European Journal of Marketing, 40(7/8), 785-802. http://dx.doi.org/10.1108/03090560610669991

Vaaland, T. I., Heide, M., \& Gronhaug, K. (2008). Corporate social responsibility: Investigating theory and research in the marketing context. European Journal of Marketing, 42(9/10), 927-953. http://dx.doi.org/10.1108/03090560810891082

Venkataraman, S., Van de Ven, A. H., Polley, D. E., \& Garud, R. (1999). The Innovation Journey. Oxford: Oxford University Press. 
Von Hippel, E. (1979). A customer-active paradigm forindustrial product idea generation. In M. Baker (Ed.), Industrial Innovation (pp. 82-110). London: The Macmillan Press.

Von Hippel, E. (1986). Lead users: A source of novel product concepts. Management Science, 32, 791-805. http://dx.doi.org/10.1287/mnsc.32.7.791

Von Hippel, E. (2001). Innovation by User Communities: Learning from Open Source Software. MIT Sloan Management Review, 42, 82-86.

Werther, W. B., \& Chandler, D. (2005). Strategic Corporate Social responsibility as global brand insurance. Bus. Horiz, 48, 317-324. http://dx.doi.org/10.1016/j.bushor.2004.11.009

Zeithaml, C. P., \& Zeithaml, V. A. (1984). Environmental Management: Revising the Marketing Perspective. Journal of Marketing, 48(2), 46-53. http://dx.doi.org/10.2307/1251213

\section{Copyrights}

Copyright for this article is retained by the author(s), with first publication rights granted to the journal.

This is an open-access article distributed under the terms and conditions of the Creative Commons Attribution license (http://creativecommons.org/licenses/by/3.0/). 